\title{
Synthesis of the C1-C9 Fragment of the Potent Antitumor Agent Dictyostatin
}

\author{
Luiz C. Dias, * Danilo P. Sant'Ana, Ygor W. Vieira, Caroline C. S. Gonçalves and Dimas J. P. Lima \\ Instituto de Química, Universidade Estadual de Campinas, CP 6154, 13083-970 Campinas-SP, Brazil
}

\begin{abstract}
Descrevemos neste trabalho uma síntese curta e eficiente para o fragmento C1-C9 do potente agente antitumoral dictiostatina. Esta abordagem sintética inclui uma reação de epoxidação assimétrica de Sharpless seguida da abertura de epóxido nas condições de Myashita para introduzir os centros estereogênicos em C6 e C7 e uma reação de olefinação tipo Horner-Wadsworth- Emmons nas condições de Ando para construir a ligação com geometria /Z/do dieno 1,3-/Z/,/E/.
\end{abstract}

We describe herein a short and efficient synthesis of the C1-C9 fragment of the potent antitumor agent dictyostatin. Notable features of this approach include a Sharpless asymmetric epoxidation followed by epoxide opening under Myashita's conditions to introduce the stereogenic centers at C6 and C7, and a Horner-Wadsworth-Emmons type reaction under Ando's conditions to construct the Z-double bond of the 1,3-(Z,E)-diene system.

Keywords: total synthesis, dictyostatin, Sharpless asymmetric epoxidation, macrolactone

\section{Introduction}

The marine-derived macrolactone dictyostatin (1) was isolated by Pettit and co-workers ${ }^{1}$ from the marine sponge Spongia sp. as well as by Wright and co-workers ${ }^{2}$ from Corallistidae sponges. Dictyostatin is a potent antitumor agent, with microtubule stabilization activity (Figure 1)..$^{3,4}$

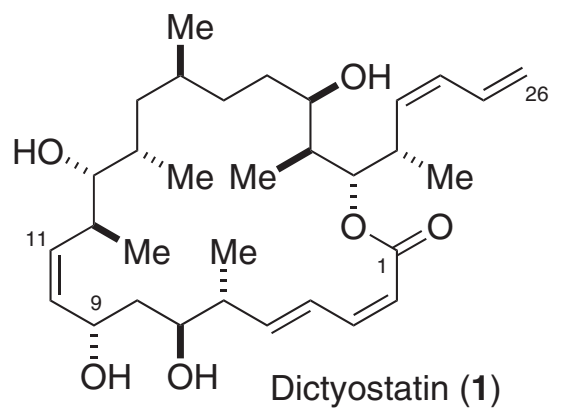

Figure 1. Structure of dictyostatin (1).

The structure of dictyostatin was deduced by Pettit and co-workers, ${ }^{1}$ and the stereochemical assignments were made on the basis of the total syntheses described by the research groups of Paterson and Curran. ${ }^{5,6}$

Due to its potent antitumor activity, a number of research groups have described the total synthesis of dictyostatin. ${ }^{5,6}$ Our research group also initiated a project

\footnotetext{
*e-mail: 1dias@iqm.unicamp.br
}

toward the total synthesis of dictyostatin, which resulted in the synthesis of the C11-C23 fragment. ${ }^{7}$ In this work we wish to describe a practical synthesis of the $\mathrm{C} 1-\mathrm{C} 9$ fragment of this potent antitumor agent.

\section{Results and Discussion}

Our approach began with monoprotection of diol 2 as the $p$-methoxybenzyl ether (Scheme 1). We have applied the strategy of creating a ketal group, followed by opening of this ketal with DIBAL-H in toluene to give the monoprotected alcohol 3 in $56 \%$ overall yield over two steps. ${ }^{8}$ Alcohol $\mathbf{3}$ was converted to the corresponding aldehyde using the Swern oxidation protocol, and the crude aldehyde was directly subjected to a Horner-WadsworthEmmons reaction to give $(E)$ - $\alpha, \beta$-unsaturated ester $\mathbf{4}$ in $70 \%$ yield $(E: Z>95: 5)$ over two steps (Scheme 1$){ }^{9}$

The ester 4 was reduced to the allylic alcohol $\mathbf{5}$ upon treatment with DIBAL-H in $\mathrm{CH}_{2} \mathrm{Cl}_{2}$ at $-40{ }^{\circ} \mathrm{C}$ in $90 \%$ yield. Overall, alcohol 5 was prepared in $35 \%$ yield after 5 steps starting from diol 2. Then, alcohol 5 was submitted to a Sharpless asymmetric epoxidation using (-)-DIPT to afford the desired epoxy alcohol 6 in $78 \%$ yield and $98 \%$ ee. The absolute configuration of epoxy alcohol $\mathbf{6}$ was confirmed by comparison of to value of the optical rotation described in the literature (observed: $[\alpha]_{\mathrm{D}}+25$, c $1.15 ; \mathrm{CHCl}_{3}$; literature: $[\alpha]_{\mathrm{D}}-25.3$ c $1.09, \mathrm{CHCl}_{3}$, for antipode epoxy alcohol 6)..$^{9,10}$ The enantiomeric excess 

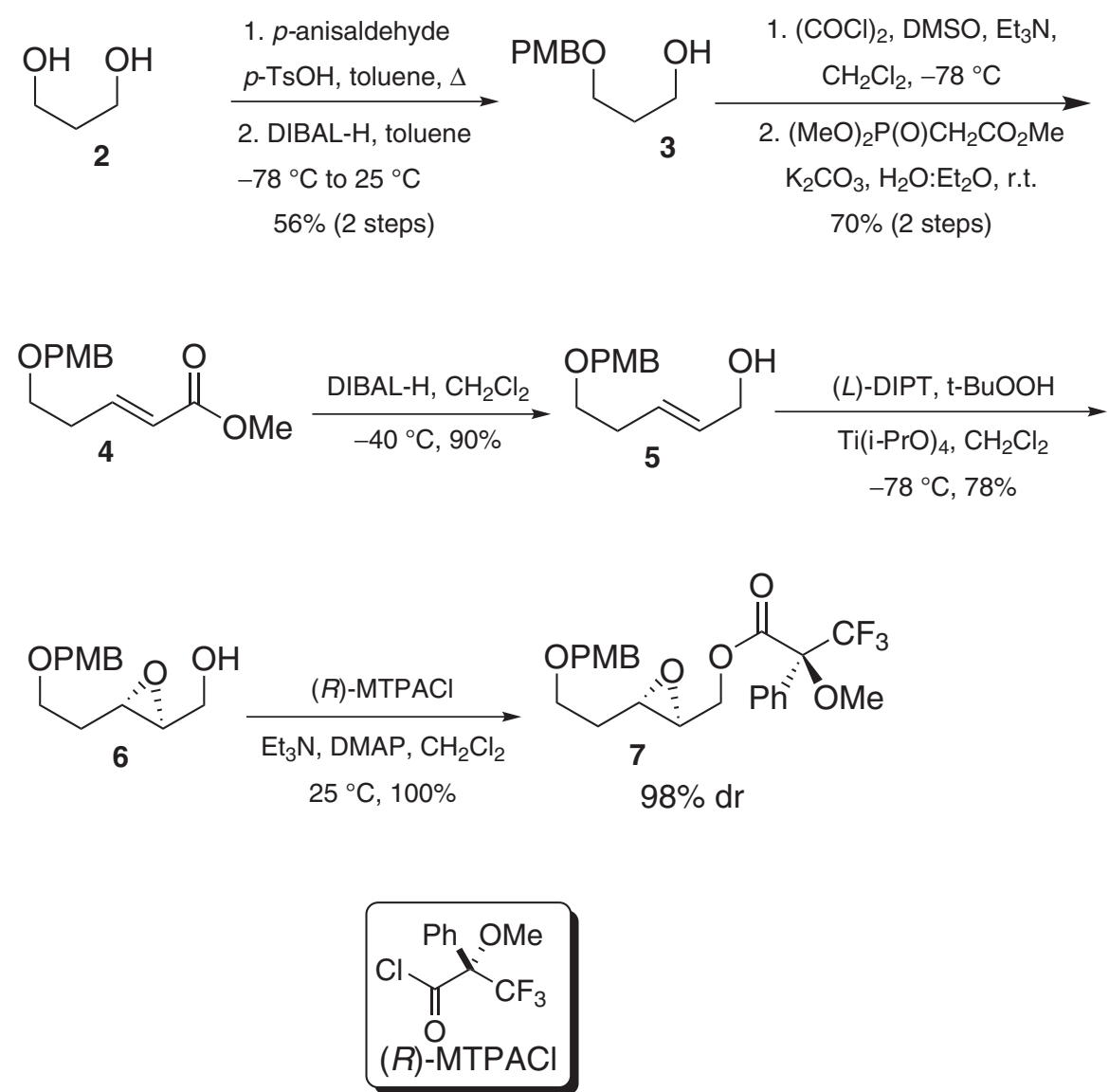

Scheme 1. Preparation of epoxy alcohol 6.

was determined using the Mosher ester method, as shown in Scheme 1. ${ }^{11}$

In addition, we have prepared allylic alcohol $\mathbf{5}$ by a shorter synthetic route (Scheme 2). ${ }^{12}$ Homoallylic alcohol 8 was converted to the corresponding $p$-methoxybenzyl ether 9 in $80 \%$ yield. A cross metathesis reaction of 9 with cis-2buten-1,4-diol (10) in the presence of Hoveyda-Grubbs second generation catalyst 11 afforded allylic alcohol 5 in $85 \%$ yield.

Based on literature precedent it seemed feasible that the regioselective nucleophilic addition of an organocuprate could be used to install the desired methyl group at the 2 position of 2,3-epoxyalkanes. ${ }^{13}$ Unfortunately, we observed poor regioselectivity, and mixtures of 1,3-diol (12) and 1,2-diol (13) were obtained (Scheme 3). In addition, the use of $n$-BuLi/Me $\mathrm{Ml}_{3} \mathrm{Al}$ led to a 20:80 mixture of $\mathbf{1 2}$ and $\mathbf{1 3}$.

To overcome this problem we decided to use Myashita's methodology for nucleophilic substitution of $\gamma, \delta$-epoxy acrylates. ${ }^{14}$ This strategy seemed promising, because nucleophilic substitution into $(E)-\gamma, \delta$-epoxy acrylate would

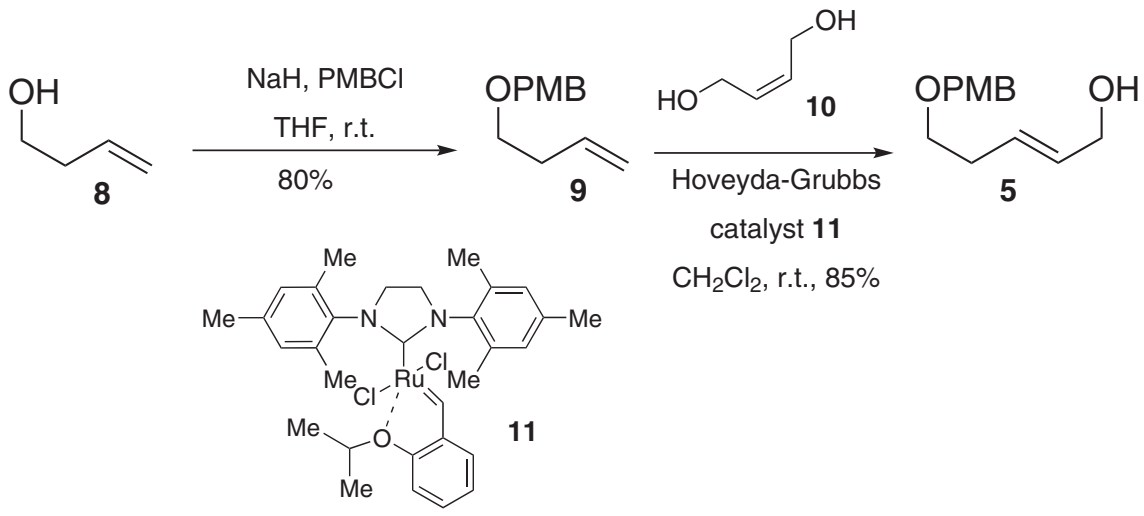

Scheme 2. Alternative preparation of allylic alcohol 5. 
1<smiles>CCCCOCC[C@@H]1O[C@@H]1CO</smiles>

6<smiles>CC(C)(C)OCC[C@H]1O[C@H]1CO</smiles>

6

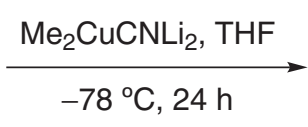

ratio $12: 13=60: 40$<smiles>CCCOCC[C@@H](O)C(C)CO</smiles>

1,3-diol (12)<smiles>CCCCC(C)C(O)CO</smiles>

1,2-diol (13)<smiles>CCCOCC[C@@H](O)C(C)CO</smiles>

1,3-diol (12)<smiles>CCCCC(C)C(O)CO</smiles>

1,2-diol (13)

Scheme 3. Attempts to synthesize the 1,3-diol.

stereospecifically provide the two stereogenic centers at C6 and $\mathrm{C}$, in an anti relationship. Moreover, the $E$ olefin of dictyostatin would already be present.

To synthesize the $(E)-\gamma, \delta$-epoxy acrylate 14 , the epoxy alcohol $\mathbf{6}$ was submitted to the Swern oxidation conditions, cleanly providing the corresponding aldehyde (Scheme 4 ). This aldehyde was used in the next step without purification to form $\mathbf{1 4}$ by a Horner-Wadsworth-Emmons reaction in $81 \%$ yield for the two-step sequence $(E: Z>95: 5)$. Next, the $(E)$ - $\gamma, \delta$-epoxy acrylate $\mathbf{1 4}$ was treated with $\mathrm{Me}_{3} \mathrm{Al}$ and $\mathrm{H}_{2} \mathrm{O}$ in dichloromethane at $-40{ }^{\circ} \mathrm{C}$, following the protocol described by Myashita and co-workers, ${ }^{14}$ which provided ester 15 in $94 \%$ yield as the only observed product. ${ }^{15}$

Subsequently, the protection of ester $\mathbf{1 5}$ was accomplished using TBSCl and imidazole in DMF, followed by treatment with DIBAL-H in dichloromethane at $-78{ }^{\circ} \mathrm{C}$ to give allylic alchol 16 in $68 \%$ yield over two steps. Oxidation of this alcohol with (bis-acetoxyiodo) benzene (BAIB) and TEMPO provided the desired aldehyde in $84 \%$ yield (Scheme 4). To prepare the C1-C9 fragment of dictyostatin, we had to construct the $2 Z, 4 E$-diene at C1-C5. ${ }^{16}$ To carry out this transformation we prepared the

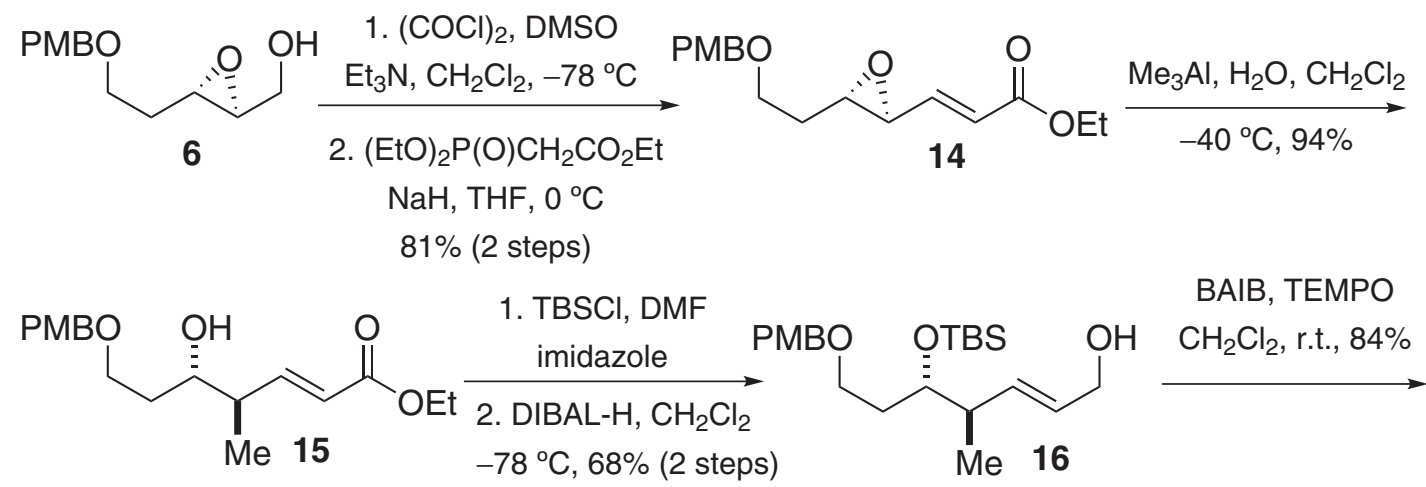

$(\mathrm{PhO})_{2} \mathrm{P}(\mathrm{O}) \mathrm{CH}_{2} \mathrm{CO}_{2} \mathrm{Et}$

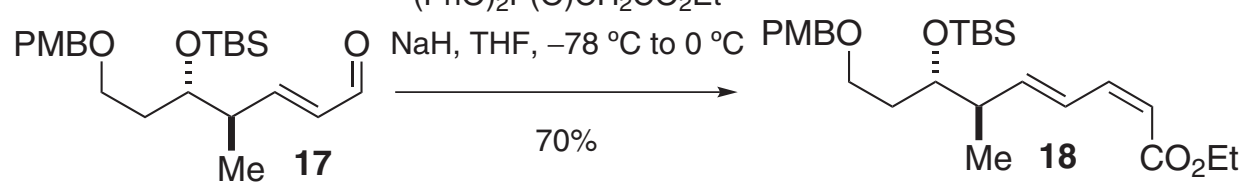

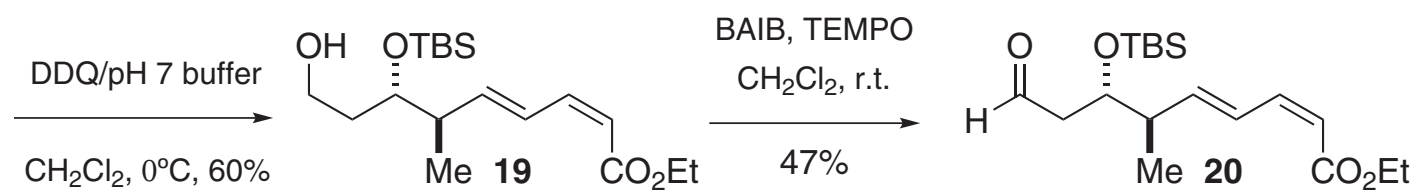

Scheme 4. Preparation of aldehyde 20. 
phosphonate ester according a method reported by Ando and co-workers. ${ }^{16}$ This phosphonate ester was deprotonated with $\mathrm{NaH}$ and the intermediate aldehyde $\mathbf{1 7}$ was added at $-78^{\circ} \mathrm{C}$. The mixture was stirred for $18 \mathrm{~h}$ at $0{ }^{\circ} \mathrm{C}$ to provide ester 18 in $70 \%$ yield ( $Z: E>95: 5)$. Oxidative removal of the PMB ether with DDQ in $\mathrm{CH}_{2} \mathrm{Cl}_{2} / \mathrm{pH} 7$ buffer (9:1) gave alcohol 19 in $60 \%$ yield. Oxidation of the hydroxyl group with BAIB and TEMPO provided the desired aldehyde $\mathbf{2 0}$ in $47 \%$ unoptimized yield (Scheme 4).

\section{Conclusions}

We have described an efficient asymmetric synthesis of the C1-C9 fragment of dictyostatin. Notable features of this approach include asymmetric Sharpless epoxidation, Myashita methodology for regioselective nucleophilic substitution on a $\gamma, \delta$-epoxy acrylate, and a HornerWadsworth-Emmons reaction using Ando's protocol to construct the 1,3-diene moiety. The synthesis required 12 steps from homoallylic alcohol $\mathbf{8}$ in $4.0 \%$ overall yield. Extension of this work toward completion of the synthesis of dictyostatin is underway, and the results will be described in due course.

\section{Acknowledgments}

We are grateful to FAEP-Unicamp, FAPESP, CNPq, and INCT-INOFAR (Proc. CNPq 573.564/2008-6) for financial support and to Prof. Carol H. Collins (IQ-Unicamp) for helpful suggestions about English grammar and style.

\section{Supplementary Information}

Product characterization as well as copies of NMR spectra for the prepared compounds are available free of charge at http://jbcs.sbq.org.br as a PDF file.

\section{References}

1. Pettit, G. R.; Cichacz, Z. A.; Gao, F.; Boyd, M. R; Schmidt, J. M.; J. Chem. Soc., Chem. Commun. 1994, 1111.

2. Isbrucker, R. A.; Cummins, J.; Pomponi, S. A.; Longley, R. E.; Wright, A. E.; Biochem. Pharmacol. 2003, 66, 75; Wright, A. E.; Cummins, J. L.; Pomponi, S. A.; Longley, R. E.; Isbrucher, R.; PCT Int. Appl. WO 0162239, 2001.

3. Pettit, G. R.; Cichacz, Z. A.; US Pat. 5430052, 1995; Curran, D. P.; Shin, Y.; Fournier, J.; Mancuso, J.; Day, B. W.; Bruckner, A.; Fukui, Y.; Curran, D.; Day, B.; US Pat. WO2005117588-A2, 2005; Curran, D. P.; Shin, Y.; Fournier, J.; Mancuso, J.; Day, B. W.; Bruckner, A.; Fukui, Y.; Curran, D.; Day, B.; Pat. AU2005249480-A1, 2005; Delgado, O.; Paterson, I.;
Britton, R.; Poullennec, K.; Meyer, A.; Wrigth, A. E.; Pat. WO2005068451-A2, 2005; Curran, D. P.; Shin, Y.; Fournier, J.; Mancuso, J.; Day, B. W.; Bruckner, A.; Fukui, Y.; Curran, D. P.; Day, B.; Pat. EP1765073-A2, 2007; Curran, D. P.; Shin, Y.; Fournier, J.; Mancuso, J.; Day, B. W.; Bruckner, A.; Fukui, Y. D.; Curran, D.; Day, B.; Pat. JP2008500370-W, 2008; Curran, D. P.; Shin, Y.; Fournier J.; Mancuso, J.; Day, B. W.; Bruckner, A; Fukui, Y.; Curran, D.; Day, B.; Pat. US7321046-B2, 2008.

4. Biological activity: Myles, D. C.; Curr. Opin. Biotechnol. 2003, 14, 6273; Madiraju, C.; Edler, M. C.; Hamel, E.; Raccor, B. S.; Balachandran, R.; Zhu, G.; Giuliano, K. A.; Vogt, A.; Shin, Y.; Fournier, J. H.; Fukui, Y.; Brückner, A. M.; Curran, D. P.; Day, B. W.; Biochemistry 2005, 44, 15053; Madiraju, C.; Raccor, B. S.; Shin, Y.; Curran, D. P.; Day, B. W.; Clin. Cancer Res. 2005, 11, 9090S; Raccor, B. S.; Vogt, A.; Sikorski, R. P.; Madiraju, C.; Balachandran, R.; Montgomery, K.; Shin, Y.; Fukui, Y.; Jung, W.H.; Curran, D. P.; Day, B. W.; Mol. Pharmacol. 2008, 73, 718; Canales, A.; Matesanz, R.; Gardner, N.; Andreu, J.; Paterson, I.; Díaz, J.; Jiménez-Barbero, J.; Chem. Eur. J. 2008, 14, 7557; Salum, L.; Dias, L. C.; Andricopulo, A.; QSAR Comb. Sci. 2009, 28, 325; Jogalekar, A. S.; Damodaran, K.; Kriel, F. H.; Jung, W.; Alcaraz, A. A.; Zhong, S.; Curran, D. P.; Snyder, J. P.; J. Am. Chem. Soc. 2011, 133, 2427; Vollmer, L. L.; Jiménez, M.; Camarco, D. P.; Zhu, W.; Daghestani, H. N.; Balachandran, R.; Reese, C. E.; Lazo, J. S.; Hukriede, N. A.; Curran, D. P.; Day, B. W.; Vogt, A.; Mol. Cancer Ther. 2011, 10, 994; Paterson, I.; Naylor, G. J.; Gardner, N. M.; Guzmán, E.; Wright, A. E.; Chem. Asian J. 2011, 6, 459.

5. Relative stereochemistry: Paterson, I.; Britton, R.; Delgado, O.; Wright, A. E.; Chem. Commun. 2004, 632.

6. Total synthesis: Paterson, I.; Britton, R.; Delgado, O.; Meyer, A.; Poullennec, K. G.; Angew. Chem. Int. Ed. 2004, 43, 4629; Paterson, I.; Britton, R.; Delgado, O.; Meyer, A.; Poullennec, K. G.; Angew. Chem. 2004, 116, 4729; Shin, Y.; Fournier, J. H.; Fukui, Y.; Brückner, A. M.; Curran, D. P.; Angew. Chem. Int. Ed. 2004, 43, 4634; Shin, Y.; Fournier, J. H.; Fukui, Y.; Brückner, A. M.; Curran, D. P.; Angew. Chem. 2004, 116, 4734; O’Neil, G. W.; Phillips, A. J.; J. Am. Chem. Soc. 2006, 128, 5340; Ramachandran, P. V.; Srivastava, A.; Hazra, D.; Org. Lett. 2007, 9, 157; Florence, G. J.; Gardner, N. M.; Paterson, I.; Nat. Prod. Rep. 2008, 25, 342; Paterson, I.; Britton, R.; Delgado, O.; Gardner, N. M.; Meyer, A.; Naylor, G. J.; Poullennec, K. G.; Tetrahedron 2010, 66, 6534; Dalby, S.; Paterson, I.; Curr. Opin. Drug. Discov. 2010, 13, 777; Zhu, W.; Jiménez, M.; Jung, W.; Camarco, D. P.; Balachandran, R.; Vogt, A.; Day, B. W.; Curran, D. P.; J. Am. Chem. Soc. 2010, 132, 9175.

7. Dias, L. C.; Lima, D. J. P.; Gonçalves, C. C. S.; Andricopulo, A. D.; Eur. J. Org. Chem. 2009, 1491.

8. Bartels, B.; Hunter, R.; J. Org. Chem. 1993, 58, 6756; Cordero, F. M.; Pisaneschi, F.; Gensini, M.; Goti, A.; Brandi, A.; Eur. J. Org. Chem. 2002, 1941. 
9. Oka, T.; Murai, A.; Tetrahedron 1998, 54, 1.

10. Hatakeyama, S.; Okano, T.; Maeyama, J.; Esumi, T.; Hiyamizu, H.; Iwabuchi, Y.; Nakagawa, K.; Ozono, K.; Kawase, A.; Kubodera, N.; Bioorg. Med. Chem. 2001, 9, 403.

11. Dale, J. A.; Mosher, H. S.; J. Am. Chem. Soc. 1973, 95, 512; Sullivan, G. R.; Dale, J. A.; Mosher, H. S.; J. Org. Chem. 1973, 38, 2143.

12. Raghavan, S.; Krishnaiah, V.; J. Org. Chem. 2010, 75, 748.

13. Chong, J. M.; Cyr, D. R.; Mar, E. K.; Tetrahedron Lett. 1987, $28,5009$.

14. Miyashita, M.; Hoshino, M.; Yoshikoshi, A.; J. Org. Chem. 1991, 56, 6483; Abe, N.; Hanawa, H.; Maruoka, K.; Sasaki, M.; Miyashita, M.; Tetrahedron Lett. 1999, 40, 5369.
15. Nakamura, R.; Tanino, K.; Miyashita, M.; Org. Lett. 2003, 5 , 3579.

16. Ando, K.; J. Org. Chem. 1997, 62, 1934; Ando, K.; J. Org. Chem. 1999, 64, 8406; Ando, K.; Oishi, T.; Hirama, M.; Ohno, H.; Ibuka, T.; J. Org. Chem. 2000, 65, 4745.

Submitted: September 22, 2011

Published online: November 29, 2011

FAPESP has sponsored the publication of this article. 